\title{
Kompetensi Profesional Guru dalam Meningkatkan Mutu Pendidikan
}

\author{
Sulastri ${ }^{\bowtie 1}$, Happy Fitria ${ }^{2}$, Alfroki Martha ${ }^{3}$ \\ (1) Sekolah Menengah Pertama Negeri 8 Prabumulih
}

(2) Universitas PGRI Palembang

$\triangle$ Corresponding author

[sulastrijihan2@gmail.com]

\begin{abstract}
Abstrak
Penelitian ini bertujuan untuk menganalisis kompetensi profesional guru dalam meningkatkan mutu pendidikan di SMP Negeri 8 Prabumulih menggunakan pendekatan kualitatif etnografi dan fenomenologis. Penelitian menggunakan sampel populasi yakni sampel penelitian sama dengan jumlah populasi yakni 62 orang guru dan pegawai. Teknis analisis data yang digunakan adalah deskriptif naratif yang diterapkan dengan tiga jalur yaitu reduksi data, penyajian data dan penarikan kesimpulan/verifikasi. Berdasarkan hasil penelitian dapat ditarik kesimpulan bahwa: 1) kompetensi Guru SMP Negeri 8 Prabumulih relatif baik; 2) upaya-upaya yang dilakukan oleh kepala sekolah dan guru dalam mengembangkan kompetensi professional dengan mengikuti diklat, pelatihan penataran, workshop, dan kelompok kerja guru, dan 3) kendala yang dihadapi diantaranya penguasaan ilmu dan teknologi yang masih kurang, kurang kreatifitas guru, guru yang mengajar bukan dibidangnya.
\end{abstract}

Kata Kunci: Kompetensi; Profesional Guru; Mutu Pendidikan

\begin{abstract}
This study aims to analyze the professional competence of teachers in improving the quality of education at SMP Negeri 8 Prabumulih using qualitative ethnographic and phenomenological approaches. The study used a population sample, namely the research sample equal to the total population, namely 62 teachers and employees. The data analysis technique used is descriptive narrative which is applied in three ways, namely data reduction, data presentation and conclusion drawing / verification. Based on the results of the study, it can be concluded that: 1) the competence of SMP Negeri 8 Prabumulih teachers is relat ively good; 2) the efforts made by school principals and teachers in developing professional competence by following training, upgrading training, workshops, and Teacher Working Groups, and 3) obstacles faced include lack of compassionate mastery of science and technology, lack of creativity of teachers, teachers who teach not in their field.
\end{abstract}

\section{Keyword: Principal Leadership; Work Motivation; Employee Performance}

\section{PENDAHULUAN}

Pendidikan adalah usaha sadar untuk menyiapkan peserta didik melalui kegiatan bimbingan, pengajaran, atau latihan bagi peranannya di masa datang. Pendidikan merupakan suatu upaya yang dirancang pemerintah untuk mecerdaskan dan memajukan bangsa. Suatu negara dapat dikatakan maju jika negara tersebut mengedepankan pendidikan, karena tanpa pendidikan suatu bangsa tidak akan memiliki kemampuan untuk mengelolah kekayaan alam, bahkan jika putra putri Indonesia tidak mempunyai skill yang memadai, dikhawatirkan akan menjadi penghambat pembangunan nasional. Hal ini perkuat oleh fakta bahwa sebagian Negara-negara maju berkembang dengan pesat bukan karena memiliki sumber alam yang melimpah ruah akan tetapi ditunjang pula dengan intelektualitas, disiplin, etos kerja rakyatnya. Education is the most important indicator of a country's progress. Quality education is certainly capable of producing quality human resources too (Asvio et al, 2019). Education itself is very useful for forming skilled and skilled development workers and can improve productivity, work quality, and work efficiency. In realizing the goals of national education, education personnel are potential human resources who play an important role. The government has made efforts to improve the quality of educational human resources. Improving the quality of educational staff or human resources of school education aims to empower teaching staff effectively and efficiently to achieve optimal results, but still in pleasant conditions (Rusdiana, 2014). Education management cannot be separated from the model or style of leadership adopted by the principal in carrying out his role as a leader. The leadership style adopted by the principal will be related to the results and effectiveness of the principal in leading and carrying out the educational process in the school (Astuti et al, 2020). Education is the spearhead 
in order to improve the quality of human resources in order to be able to compete in the midst of competition for increasingly advanced and modern national life. Education is a long-term investment and is the key to a better future in the life of the nation and state. Without adequate and quality education, the Indonesian people will be increasingly left behind with other nations (Hartiwi et al, 2020).

Pendidikan juga merupakan usaha sadar dan terencana untuk mewujudkan suasaa belajar dan proses pembelajaran agar peserta didik secara aktif mengembangkan potensi dirinya untuk memiliki pengendalian, kepribadian, kecerdasan, akhlak mulia, serta keterampilan. Dengan demikian, pendidikan sebagai salah satu instrumen utama dalam pengembangan sumber daya manusia yang penyelenggaraannya dapat dilakukan secara demokratis dan berkeadilan serta tidak diskriminatif. Education is one of the most important and strategic aspects in the development and improvement of development in all fields, including in the regions, so that the decentralization of education in the context of regional autonomy cannot be negotiated in order to improve the quality of education and human resources (Rohma et al, 2020).

Subjek utama dalam proses pengembangan itu dilakukan oleh tenaga kependidikan yang berasal dari anggota masyarakat yang mengabdikan diri dan diangkat untuk menunjang penyelenggaraan pendidikan dengan sasaran untuk mengembangkan kemampuan dan membentuk watak serta peradaban bangsa yang bermartabat dalam rangka mencerdaskan kehidupan bangsa.

Maka kualitas manusia yang diinginkan oleh bangsa Indonesia pada masa yang akan datang adalah yang mampu menghadapi persaingan yang semakin ketat dengan bangsa lain di dunia. Kualitas manusia Indonesia tersebut dihasilkan melalui penyelenggaraan pendidikan yang bermutu. Oleh sebab itu, guru mempunyai fungsi, peran, dan kedudukan yang sangat penting. Itulah sebabnya, guru harus senantiasa mengembangkan kemampuan dirinya. Guru perlu memiliki standar profesi dengan menguasai materi serta strategi pembelajaran dan dapat mendorong siswanya untuk belajar sungguh-sungguh.

Menurut Undang-Undang Republik Indonesia Nomor 14 Tahun 2005 tentang Guru dan Dosen Pasal 2 ayat 1 menegaskan bahwa guru mempunyai kedudukan sebagai tenaga profesional pada jenjang pendidikan dasar, pendidikan menengah, dan pendidikan anak usia dini pada jalur pendidikan formal yang diangkat sesuai dengan peraturan perundang-undangan. Pada Pasal 4 juga dijelaskan bahwa kedudukan guru sebagai tenaga professional sebagaimana dimaksud dalam Pasal 2 ayat 1 berfungsi untuk meningkatkan martabat dan peran guru sebagai agen pembelajaran berfungsi untuk meningkatkan mutu pendidikan nasional. The teacher as an educator should pay attention to various developments in the world of education. A change is needed in the application of concepts or ideas that require work patterns. The pattern of work can be appropriate, if the capabilities possessed are supported by knowledge and motivation (Darmiati et al, 2020). Teachers who have been the only main role in providing scientific education services willgradually be displaced along with the times. In order to remain needed and meaningful in their existence in the classroom, therefore teachers must always be required to innovate and have creativity as needed (Suratman et al, 2020). As stated by Kristiawan et al (2019); Kristiawan (2015) that to optimize the ability of students, readiness of human resources, develop student character values, digital-based learning facilities and infrastructure, appropriate curricula and policies in education are some of the solutions that need to be done in the world of education.

Dalam menciptakan mutu pendidikan sosok guru yang mempunyai kualifikasi, kompetensi, dan dedikasi yang tinggi dalam menjalankan tugas profesionalnya sangat dibutuhkan. Guru merupakan kunci keberhasilan suatu lembaga pendidikan. Baik buruknya perilaku atau tata cara mengajar guru akan sangat mempengaruhi citra lembaga pendidikan. Tanpa adanya sumber daya guru yang profesional mutu pendidikan tidak akan meningkat. Karena dalam pelaksanaan pendidikan sekolah sangat ditekankan adanya peningkatan mutu sebagai jawaban terhadap kebutuhan dan dinamika masyarakat yang sedang berkembang, sehingga peningkatan mutu dapat diwujudkan melalui pelaksanaan pendidikan. In another hand, from the perspective of education and educational background, it has not fulfilled the expectation so that it can be considered that the teacher is not professional yet. This indicator is shown quantitatively upon the condition in Indonesia as follow: the low quality caused by various determining variables such as variable of curriculum, learning media, lack of facility, parents and society support, headmaster management, natural environment, less supporting social and culture and the last but not the least is teacher (Wachidi et al, 2020).

Sejalan dengan hal itu, seperti yang tertera dalam UU RI no. 14 tahun 2005 Bab II Pasal 2 ayat 1 menyatakan: guru mempunyai kedudukan sebagai tenaga profesional pada jenjang pendidikan dasar, pendidikan menengah, dan pendidikan anak usia dini pada jalur pendidikan formal yang diangkat sesuai dengan peraturan perundang-undangan.

Guru merupakan suatu profesi, yang berarti suatu jabatan yang memerlukan keahlian khusus sebagai guru dan tidak dapat dilakukan oleh sembarang orang di luar bidang pendidikan. Tugas guru sebagai suatu profesi meliputi mendidik, mengajar dan melatih. Mendidik berarti meneruskan dan mengembangkan nilainilai hidup. Mengajar berarti meneruskan dan mengembangkan ilmu pengetahuan dan teknologi, sedangkan melatih berarti mengembangkan ketrampilan-ketrampilan pada peserta didik. Mengenai hasil, guru dikatakan berhasil apabila mampu mengubah prilaku sebagian besar peserta didik ke arah penguasaan kompetensi dasar yang lebih baik (Afriyanli and Sabandi, 2020). 
Guru merupakan pihak pemegang kunci dari menarik serta efektif tidaknya suatu proses pembelajaran, karena itu seorang guru tidak hanya di tuntut mampu menghidupkan suasana kelas tetapi juga mampu untuk menjadikan pembelajaran menjadi suatu proses dalam peningkatan kepribadian bagi peserta didik. Upaya dalam meningkatkan kualitas pendidik dan tenaga kependidikan untuk menyelesaikan masalah yang dihadapi saat menjalankan tugasnya guru akan memberi dampak positif yaitu pertama, penyelesaian masalah pendidikan dan pembelajaran melalui sebuah investigasi terkendali akan dapat meningkatkan kualitas isi, masukan, proses, dan hasil belajar; kedua, kemampuan dalam menyelesaikan masalah pendidikan yang nyata akan semakin meningkat; dan ketiga, peningkatan profesionalisme pendidik dan tenaga kependidikan lainnya. Guru profesional akan terlihat melalui tanggung jawabnya sebagai seorang guru dalam melaksanakan seluruh pengabdiannya. Guru profesional mampu memikul dan melaksanakan tanggung jawabnya kepada peserta didik, orang tua, masyarakat, bangsa, negara dan agamanya. Guru profesional mempunyai tanggung jawab sosial diwujudkan melalui kompetensi guru dari lingkungan sosial serta memiliki kemampuan interaktif yang efektif (Fitria et al, 2019).

Guru memiliki kualifikasi akademik, kompetensi, sertifikat pendidik, sehat jasmani dan rohani, serta mampu untuk mewujudkan tujuan pendidikan nasional. Kompetensi guru meliputi kompetensi pedagogik, kompetensi kepribadian, kompetensi sosial dan kompetensi profesional yang diperoleh melalui pendidikan profesi. Masalah kompetensi profesional guru merupakan salah satu dari tenaga kependidikan memiliki tanggung jawab untuk mengembangkan tugas itu.

Profesionalisme adalah kebutuhan yang tidak dapat tunda lagi, semakin meningkatnya persaingan yang semakin ketat dalam era globalisasi maka perlu ditingkatkan lagi profesionalisme dari seorang guru. Untuk meningkatkan profesionalisme guru maka guru dituntut untuk melakukan proses pembelajaran yang lebih inovatif kepada peserta didik. Kompetensi profesional meliputi sebagai berikut, 1) menguasai struktur dan materi kurikulum bidang studi; 2) menguasai substansi bidang studi dan metodologi keilmuannya; 3) menguasai dan memanfaatkan teknologi informasi dan komunikasi dalam pembelajaran; 4) mengorganisasikan materi kurikulum bidang studi; dan 5) meningkatkan kualitas pembelajaran melalui penelitian tindakan kelas (Kristiawan \& Rahmat, 2018).

Pengertian tenaga kependidikan dapat dilihat dalam ketentuan umum Undang-undang Nomor 20 Tahun 2003 tentang Sistem Pendidikan Nasional pasal 1 ayat 5, menjelaskan bahwa tenaga kependidikan adalah anggota masyarakat yang mengabdikan diri dan diangkat untuk menunjang penyelenggaraan pendidikan.

Di samping itu, kedudukan guru sebagai tenaga kependidikan yang profesional bertujuan untuk melaksanakan sistem pendidikan nasional dalam mewujudkan tujuan pendidikan nasional, yaitu berkembangnya potensi peserta didik agar menjadi manusia beriman dan bertaqwa, berilmu, cakap, serta kreatif.

Profesi guru telah hadir cukup lama di negara Indonesia, meskipun hakikat, fungsi, latar tugas, dan kedudukan sosiologisnya telah banyak mengalami perubahan. Sejalan dengan kenyataan itu, keberhasilan pembangunan nasional akan ditentukan oleh keberhasilan dalam mengelola pendidikan nasional dimana di dalamnya guru menempati posisi utama dan penting.

Maka dari itu tidak dapat dipungkiri bahwa guru harus memiliki pengetahuan yang luas, menguasai berbagai jenis bahan pembelajaran, menguasai teori dan praktik pendidikan, serta menguasai kurikulum dan metodologi pembelajaran.

Kompetensi guru adalah salah satu faktor yang mempengaruhi tercapainya tujuan pembelajaran dan pendidikan di SMP Negeri 8 Prabumulih, namun kompetensi guru tidak berdiri sendiri, tetapi dipengaruhi latar belakang pendidikan, pengalaman mengajar, dan lamanya mengajar. Kompetensi guru dapat dinilai penting sebagai alat seleksi dalam penerimaan calon guru, juga dapat dijadikan sebagai pedoman dalam rangka pembinaan dan pengembangan tenaga guru. Selain itu, penting dalam hubungannya kegiatan belajar mengajar dan hasil belajar siswa.

Dengan kompetensi profesional tersebut, dapat diduga berpengaruh pada proses pengelolaan pendidikan sehingga mampu menghasilkan pendidikan yang bermutu profesi. Masalah kompetensi profesional guru merupakan salah satu dari kompetensi profesional guru memegang peranan penting untuk meningkatkan mutu pembalajaran sisiwa, di sekolah ini sering ada siswa yang malas, sering keluar masuk kelas ketika jam belajar sedang berlangsung dengan alasan ingin pergi ke kamar mandi dan terkadang tidak memperhatikan pelajaran. Apabila kondisi ini tejadi dapat diartikan bahwa guru dianggap tidak berhasil menciptkan mutu pembelajaran yang tepat dalam proses belajar mengajar dan kurangnya motivasi kepada siswa agar dapat giat belajar.

Di zaman globalisasi ini kemajuan ilmu pengetahuan dan teknologi yang semakin canggih dan mengalami pertukaran yang sangat cepat. Profesionalisme dalam bidang tersebut sangat diharuskan, terutama profesionalisme guru. Guru yang peka dan tanggap terhadap perubahan-perubahan, pembaharuan serta ilmu pengetahuan dan teknologi yang terus berkembang sejalan dengan kebutuhan masyarakat dan 
perkembangan zaman. Di sinilah tugas guru untuk senantiasa meningkatkan mutu pendidikan sehingga apa yang diajarkan jelas dan mampu diserap oleh peserta didiknya.

Dari penjelasan di atas, memberikan pandangan bahwa pendidikan harus diarahkan untuk menghasilkan kualitas manusia yang mampu bersaing, di samping memiliki budi pekerti yang luhur. Kualitas sebuah negara dapat dilihat dari beberapa faktor, di antaranya adalah faktor pendidikan. Sekolah merupakan sebuah lembaga yang dipersiapkan untuk menyediakan kebutuhan sumber daya manusia yang berkualitas. Sumber daya manusia yang berkualitas akan meningkatkan kualitas suatu negara. Oleh karena itu, upaya meningkatkan kualitas sumber daya alam tidak dapat terpisah dari pendidikan (Rahmadoni, 2018).

Tugas dan peran guru dari hari kehari semakin berat, seiring dengan perkembangan ilmu pengetahuan dan teknologi. Guru sebagai komponen utama dalam dunia pendidikan dituntut untuk mampu mengimbangi bahkan melampaui perkembangan ilmu pengetahuan dan teknologi yang berkembang dalam masyarakat. Melalui sentuhan guru di sekolah, diharapkan mampu menghasilkan peserta didik yang memiliki kompetensi tinggi dan siap menghadapi tantangan hidup dengan penuh keyakinan dan percaya diri yang tinggi sekarang dan ke depan, sekolah/pendidikan harus mampu menciptakan mutu pendidikan, baik secara keilmuan/akademis maupun secara sikap mental.

Kompetensi profesional guru sangat dibutuhkan upaya proses pembelajaran yang lebih baik, sehingga peserta didik akan termotivasi untuk belajar dan berprestasi. Karena guru yang professional akan mampu melakasanakan strategi pembelajaran dan menyajikan materi dengan baik dan menyenagkan dan tidak hanya berorentasi kepada ketuntasa belajar saja tetapi pada proses tumbuh kembang potensi peserta didik yang meliputi aspek kognitif, afektif dan psikomotorik. Berdasarkan pegamatan beberapa kelas di SMPN 8 Prabumulih juga masih banyaknya guru menggunakan metode konvesional seperti halnya metode ceramah, jadi disini guru yang lebih aktif dalam proses pembelajaran dibandingkan siswa. Dalam penguasaan materi pelajaran yang meliputi sistematika dalam penyampaian, tepat dalam memberikan contoh, mampu menjawab pertanyaan serta kualitas dalam menjelaskan, cenderung akan menciptakan mutu pembelajaran, hal ini terbukti bahwa semakin guru tidak menguasai materi pelajaran maka hasil belajar siswa akan menurun.

Demikian halnya yang berlangsung di SMP Negeri 8 Prabumulih, sarat dengan prestasi baik dari segi pendidiknya maupun siswanya. Beberapa gurunya pernah meraih predikat sebagai guru berprestasi dan sebagai guru teladan. Hal ini diraih tentunya karena adanya kompetensi yang dimiliki oleh guru-guru SMP Negeri 8 Prabumulih khususnya kompetensi profesional sehingga SMP Negeri 8 Prabumulih banyak meraih prestasi.

Penelitian ini bertujuan untuk mengkaji dan mendiskusikan secara mendalam strategi pengembangan profesional guru di SMP Negeri 8 dengan fokus pembahasan pada: 1) strategi dan metode pembelajaran di SMP Negeri 8 Prabumulih; 2) kendala yang dihadapi dalam mengembangkan kompetensi professional; 3) model pengembangan kompetensi profesional guru yang disarankan ke depan, dan 4) upaya dalam meningkatkan kompetensi profesional.

Adapun alasan penulis memilih penelitian di SMP Negeri 8 prabumulih karena sekolah tersebut menyandang sebagai sekolah model. Karena pada dasarnya sekolah model adalah sekolah yang memiliki guru yang profesional apakah pada kenyataannya itu benar atau tidak. Berdasarkan latar belakang diatas. Maka penulis tertarik untuk meneliti mengenai "Kompetensi Profesional Guru Dalam meningkatkan mutu Pendidikan di SMP Negeri 8 Prabumulih"

\section{METODE PENELITIAN}

Penelitian ini dilakukan dengan menggunakan pendekatan kualitatif etnografi dan fenomenologis, yaitu penelitian yang menekankan pada kualitas atau hal yang terpenting dari suatu kejadian, fenomena, atau gejala sosial yang dapat dijadikan sebagai pelajaran berharga bagi suatu pengembangan konsep teori.

Penelitian kualitatif ini dilakukan karena peneliti ingin mengungkap fenomena-fenomena yang tidak dapat dikuantifikasikan yang bersifat deskriptif seperti proses suatu langkah kerja, formula suatu resep, pengertian- pengertian tentang suatu konsep yang beragam, karakteristik suatu barang dan jasa, gambargambar, gaya-gaya, tata cara suatu budaya dan lain sebagainya.

Menurut pendapat Sutopo (2002) di dalam penelitian kualitatif: 1) kondisi subjek sama sekali tidak dijamah oleh perlakuan/ treatment yang dikendalikan secara ketat oleh peneliti; 2) peneliti hanya berfungsi sebagai motivator dan fasilitator bagi berlangsungnya kegiatan tersebut, dan 3) peneliti menjelajahi kancah dan menggunakan sebagian besar waktunya dalam mengumpulkan data secara langsung dan data yang didapat benar-benar berdasarkan perspektif subjek yang diteliti.

Penelitian ini menggunakan desain etnografi sehingga desain tersebut sering disebut dengan penelitian etnometodologi. Inti dari etnografi adalah upaya untuk memperhatikan makna-makna tindakan dari kejadian yang menimpa orang yang ingin dipahami. Penelitian menggunakan sampel populasi yakni sampel penelitian sama dengan jumlah populasi yakni 62 orang guru dan Pegawai. Teknis analisis data yang digunakan adalah deskriptif naratif yang diterapkan dengan tiga jalur yaitu reduksi data, penyajian data dan 
penarikan kesimpulan/verifikasi. Pemeriksaaan atau pengecekan ke absahan data/triangulasi yang dilakukan melalui konfrontatif analisis

\section{HASIL DAN PEMBAHASAN}

Dalam meningkatkan kompetensi profesional guru serta mutu pendidikan kepala sekolah selalu berupaya memotivasi dan memfasilitasi guru di SMP Negeri 8 Prabumulih untuk mengembangkan ke profesionalan mereka. Profesionalisme guru itu sangat ideal, berarti sesuatu yang tidak mustahil untuk segera diwujudkan, guru yang profesional punya tantangan tersendiri ketika dia berkecimpung serta bertanggung jawab terhadap pekerjaan sebagai seorang guru. Setiap guru selalu berusaha menjadi guru yang memiliki prestasi kerja yang bisa meningkat mutu pendidikan di SMP Negeri 8 Prabumulih. Oleh sebab itu tantangan itu diharapkan tepat sasaran tujuan pendidikan untuk menghasil produk pendidikan yang baik.

Upaya yang dilakukan oleh Kepala Sekolah dalam meningkatkan kompetensi profesional guru di SMP Negeri 8 Prabumulih adalah: 1) pembinaan kompetensi guru, pihak sekolah telah memfasilitasi para guru untuk: a) kursus komputer di sekolah, sehingga dalam proses pembelajaran para guru di sekolah ini telah menggunakan laptop sebagai media; b) pelatihan guna mengembangkan potensi tenaga pendidik, maupun kegiatan mandiri dengan bekerja sama dengan guru yang menjadi operator computer, dan c) membentuk forum diskusi guru atau lebih dikenal di masyarakat luas sebagai Kelompok Kerja Guru. Dalam forum diskusi guru diharapkan ada sharing konwledge, peer teaching dan berbagi pengalaman antar guru serta memecahkan masalah yang dihadapi Guru di kelas-kelas mereka; 2) penyediaan dan pengembangan sumber dan media belajar; 3) pengelolaan lingkungan belajar; yaitu dengan melakukan pembenahan lingkungan belajar baik di dalam maupun diluar kelas agar terbentuk lingkungan yang ASRI (aman, sehat, resik dan indah). Kelas-kelas diharapkan terkelola dengan baik dengan lebih banyak menampilkan informasi yang bersifat mendidik dan memberikan motivasi belajar. Dalam konteks ini maka semua siswa, guru dan karyawan diharapkan senantiasa menjaga dan mewujudkan lingkungan belajar yang bersih dan kondusif; 4) pembangunan elearning, dimana langkah-langkah yang sedang dan akan dilakukan diantaranya mengoptimalkan penggunaan komputer untuk pembelajaran. Penggunaan Televisi maupun VCD, CD dan DVD yang dapat direkayasa untuk pembelajaran; 5) pengontrolan mutu proses pembelajaran dengan cara Kepala Sekolah memberikan kebijakan agar semua guru pernah mengalami supervisi terjadwal maupun supervisi tidak terjadwal yang dilakukan oleh Kepala Sekolah, wakil Kepala kurikulum maupun bagian akademik. Supervisi dilakukan bukan semata terhadap pelasanaannya, namun dari perencanaan, pelaksanaan hingga evaluasi tidak luput dari supervisi, dan 6) pembinaan siswa dengan cara penanaman sikap disiplin belajar, tertib dalam pelaksanaan, tuntas dalam pekerjaan dan beramal baik dalam keseharian merupakan hal-hal positif dalam pembelajaran di kelas. Pelibatan siswa dalam penigkatan mutu pembelajaran tidak semata terkait dengan kedisipilinan dan sikap selama pembelajaran namun juga dilakukan penanaman motivasi belajar melalui intervensi aspek internal dan eksternal siswa. Terkait intervensi aspek internal siswa, madrasah melakukan kegiatan pembinaan rutin, baik yang dilaksanakan setiap pekan melalui bimbingan pada upacara bendera setiap hari senin, maupun setiap hari melalui kegiatan pembelajaran di kelas oleh guru mata pelajaran ataupun guru kelasnya masing-masing.

Sedangkan upaya guru dalam mengembang kompetensi profesional di SMP Negeri 8 Prabumulih dengan mengikuti berbagai kegiatan keprofesionalanya seperti: MGMP/musyawarah guru mata pelajaran, penataran, workshop-workshop serta pelatihan-pelatihan. Hal ini senada dengan yang dijelaskan oleh Ibu $\mathrm{Hj}$. Idawati, S. Pd, M. Si, bahwa ada beberapa alternatif pengembangan profesi yang dapat dilakukan guru, yaitu: 1) program-program penataran atau kursus-kursus, kegiatan-kegiatan ilmiah, dan Workshop. Untuk hal tersebut kepala sekolah sangat mendukung bagi peningkatan kompetensi guru melalui kegiatan diklat maupun workshop yang bekerja sama dengan palcomtech kota Prabumulih. Untuk meningkatkan profesionalisme guru, pihak sekolah mewajibkan para guru mengikuti Kelompok Kerja Guru dan Musyawarah Guru Mata Pelajaran yang dilaksanakan satu bulan sekali. Kepala sekolah juga sering mengutus para guru untuk mengikuti diklat maupun workshop yang dilaksanakan oleh Dinas Pendidikan kota Prabumulih; 2) sikap pro-aktif guru dalam mengembangkan wawasan kependidikan sesuai dengan bidangnya, ini dapat dilakukan dengan keikut sertaan guru dalam pelatihan-pelatihan atau seminar dengan inisiatif sendiri dan biaya sendiri, dan 3) penelitian tindakan kelas, di samping kegiatan diklat maupun workshop, upaya meningkatkan keprofesionalan kerja serta mutu pembelajaran menurut Ibu Hj. Idawati, S. Pd, M. Si dilakukan dengan penelitian tindakan kelas. Menurutnya, Seorang guru merupakan arsitek dalam pembelajaran sekaligus juga sebagai pelaksana termasuk di dalamnya melakukan evaluasi. Untuk merencanakan, melaksanakan proses pembelajaran yang bermutu, menilai, dan mengevaluasi hasil pembelajaran diperlukan sebuah penelitian tindakan kelas. Penelitian tindakan kelas adalah penelitian yang dilakukan oleh guru di kelasnya sendiri dengan jalan merencanakan, melaksanakan, mengamati, dan melakukan refleksi diri melalui siklus-siklus yang bertujuan untuk meningkatkan mutu pembelajaran. Penelitian tindakan kelas dapat membantu guru memperbaiki mutu pembelajaran, meningkatkan profesionalitas guru, meningkatkan rasa percaya diri guru, memungkinkan guru secara aktif mengembangkan pengetahuan, dan keterampilannya. Selain itu, penelitian 
tindakan kelas akan menumbuhkan budaya meneliti di kalangan guru yang merupakan dampak dari pelaksanaan tindakan secara berkesinambungan, maka manfaat yang dapat diperoleh secara keseluruhan yaitu label inovasi pendidikan karena para guru semakin diberdayakan untuk mengambil berbagai prakarsa profesional secara mandiri. Sikap mandiri akan memicu lahirnya percaya diri untuk mencoba hal-hal baru yang diduga dapat menuju perbaikan sistem pembelajaran. Sikap ingin selalu mencoba akan memicu peningkatan kinerja dan profesionalisme seorang guru secara berkesinambungan. Sehingga proses belajar sepanjang hayat terus terjadi pada dirinya.

Dilihat dari sumber dayanya guru - guru di SMP Negeri 8 Prabumulih sudah sudah menggunakan teknologi dan menggunakan media pembelajran walaupun masih sederhana, namun media pembelajaran yang berbasis teknologi masih minim jumlahnya, seperti laptop, LCD dan ruang multimedia namun secara umum guru di SMP Negeri 8 meberikan penilaian dalam pembelajaran sudah menggunakan teknologi.

Kendala-kendala yang di hadapi dalam pengembangan kompetensi profesional guru diantaranya: 1) kurangnya motivasi dalam bekerja. Sebagian kecil guru masih ada yang rendah motivasinya untuk meningkatkan kompetensinya. Sikap konservatif yang dimiliki oleh guru membawa dampak bagi lemahnya motivasi bagi guru untuk melakukan perubahan; 2) dana, masalah klasik ini selalu menjadi penentu. Namun demikian dengan keterbatasan dana sekolah tetap berusaha semaksimal mungkin untuk memfasilitasi setiap usaha guna meningkatkan kompetensi guru. Terbatasnya sarana prasarana, Sarana dan prasarana yang ada belum memadai untuk memenuhi semua kebutuhan guru dalam pelaksanaan pembelajaran; 3) penguasaan ilmu teknologi yang masih kurang. Pada era sekarang ini zaman sudah canggih sebagian besar pekerjaan sudah bisa dilakuan dengan menggunak ilmu pengetahuan teknologi. Dengan kemajuan tersebut terdapat kendala dalam mengembangkan kompetensi profesional guru, tanpa terkecuali di SMP Negeri 8 Prabumulih kenyataaan yang ada dilapangan. Kepala Sekolah selalu berusaha mencari solusi untuk membantu guru para untuk bisa melaksanakn tugasnya dengan baik. Pada era pandemi ini pembelajaran online yang menggunakan IT, karena adanya keterbatasan agar bisa mengajar, maka pihak sekolah memfasiltasi belajar di ruang komputer dibantu oleh operator komputer untuk mentranferkan materi pembelajran melalui google classroom; 4) guru mengajar bukan pada bidangnya. Dalam proses belajar dan mengajar masih terdapat kendala yang dialami oleh beberapa guru di SMP Negeri 8 Prabumulih yang berkualifikasi pendidikan bahasa inggris mengajar bidang studi seni budaya. Ada juga yang memiliki kualifikasi IPS mengajar bidang studi prakarya. Disatu sisi hal ini disebabkan banyaknya guru yang sudah sertifikasi yang dituntut harus menjar 24 jam pelajaran, sedang jam pelajaran disini belum cukup jadi yang belum sertifikasi di berikan mangajar di bidang studi yang cenderung kekurangan gurunya. Kurangnya kreatifitas guru. Oleh karena itu kepala sekolah berusaha memnuhi bidang studi yaang mengalami kurangnya guru dengan bidang studi yang gurunya dianggap lebih.

Untuk itulah maka keberhasilan sebuah pembelajaran setidaknya dipengaruhi oleh 5 komponen kunci, yaitu: guru, sumber dan media belajar, lingkungan, siswa, dalam proses pembelajaran. Jadi guru dalam pembelajaran memiliki peran yang sangat strategis. Jika kepala madrasah adalah penentu kebijakan dalam lembaga, maka guru adalah pelaksana dan orang yang terjun langsung dalam proses pendidikan yang berada dalam kelas.

\section{SIMPULAN}

Untuk menghasilkan mutu pendidikan yang lebih baik kepemimpinan Kepala Sekolah dan kreatifitas guru yang professional, inovatif, kreatif, merupakan salah satu tolok ukur dalam peningkatan mutu pembelajaran di sekolah, karena kedua elemen ini merupakan figur yang bersentuhan langsung dengan proses pembelajaran, kedua elemen ini merupakan figur sentral yang dapat memberikan kepercayaan kepada masyarakat/ orang tua, siswa, kepuasan masyarakat akan terlihat dari output dan outcome yang dilakukan pada setiap periode. Kompetensi professional guru SMP Negeri 8 Prabumulih dalam meningkatkan mutu pendidkan dapat disimpulkan sebagai berikut: 1) kompetensi Guru SMP Negeri 8 Prabumulih relatif baik, dimana semua guru berpredikat sarjana, memiliki perangkat pembelajaran, menerapkan pembelajaran dengan model pembelajaran kooperatif, sudah tersertifikasi, dan ada yang berprestasi padatingkat propinsi. Kompetensi guru yang baik sangat berpengaruh kepada kualitas pembelajaran dan mutu pendidikan, demikian yang terjadi di SMP Negeri 8 Prabumulih sehingga banyak prestasi yang diraih oleh para siswa baik dalam bidang kokurikuler maupun ekstrakulikuler; 2) upaya-upaya yang dilakukan oleh kepala sekolah dan guru dalam mengembangkan kompetensi professional dengan mengikuti diklat, pelatihan penataran, workshop, dan kelompok kerja guru, menciptakan suatu hasil melalui penelitian tindakan kelas atau inovasi secara langsung yang bisa diberikan kepada peserta didik agar menghasil output yang lebih baik dan tangguh bersaing di dunia pendidikan ataupun di masyarakat, dan 3) kendala yang dihadapi dalam mengembangkan kompetensi profesional guru dalam meningkatkan mutu pendidikan di SMP Negeri 8 Prabumulih, adapun kendala-kendala diantaranya penguasaan ilmu dan teknologi yang masih kurang, kurang kreatifitas guru, guru yang mengajar bukan dibidangnya. 


\section{UCAPAN TERIMA KASIH}

Terima kasih yang sebesar-besarnya kami ucapkan kepada Kepala Sekolah SMP Negeri 1 Kecamatan Sekayu, SMP Negeri 2 Kecamatan Sekayu, SMP Negeri 5 Kecamatan Sekayu, Rektor Universitas PGRI Palembang, Direktur Program Pascasarjana Universitas PGRI Palembang dan Program Studi Manajemen Pendidikan Universitas PGRI Palembang yang telah memberikan dukungan kepada kami untuk melakukan hal yang luar biasa ini. Proyek ini didanai secara independen. Kami juga ingin berterima kasih kepada temanteman kami di Manajemen Pendidikan yang banyak membantu kami dalam menyelesaikan proyek ini dalam jangka waktu yang terbatas.

\section{DAFTAR PUSTAKA}

Afriyanli, H. K \& Sabandi, A. (2020). Pengaruh Supervisi Kepala Sekolah terhadap Kinerja Guru. Jurnal Manajemen, Kepemimpinan dan Supervisi Pendidikan 5(1), Januari-Juni 2020.

Alamsyah, M., Ahmad, S., \& Harris, H. (2020). Pengaruh Kualifikasi Akademik dan Pengalaman Mengajar terhadap Profesionalisme Guru. Journal of Education Research, 1(3), 1830187. doi:https://doi.org/10.37985/joe.v1i3.19

Astuti, R. W., Fitria, H., \& Rohana, R. (2020). The Influence of Leadership Styles and Work Motivation on Teacher's Performance. Journal of Social Work and Science Education, 1(2), 105-114. Retrieved from https://ejournal.karinosseff.org/index.php/jswse/article/view/33

Asvio, N., Yamin, M., \& Risnita. (2019). Influence of Leadership Style, Emotional Intelligence and Job Satisfaction toward Organizational Commitment (Survey at SMA Muhammadiyah South Sumatera). International Journal of Scientific \& Technology Research 8 (8).

Darmiati, D., Kristiawan, M., \& Rohana, R. (2020). The Influence of School Leadership and Work Motivation toward Teacher's Discipline. Journal of Social Work and Science Education, 1(1), 32-44. Retrieved from https://ejournal.karinosseff.org/index.php/jswse/article/view/8

Fitria, H., Kristiawan, M., \& Rahmat, N. (2019). Upaya Meningkatkan Kompetensi Guru Melalui Pelatihan Penelitian Tindakan Kelas. ABDIMAS UNWAHAS, 4(1).

Hartiwi, H., Kozlova, A. Y \& Masitoh, F. (2020). The Effect of Certified Teacher and Principal Leadership Toward Teacher's Performance. International Journal of Educational Review Vol. 2, Issue 70-88. Retrieved from https://ejournal.unib.ac.id/index.php/IJER/article/view/10629

Juniarti, E., Ahyani, N., \& Ardiansyah, A. (2020). Pengaruh Kepemimpinan Kepala Sekolah dan Disiplin Guru terhadap Kinerja Guru. Journal of Education Research, 1(3), 193-199. doi:https://doi.org/10.37985/joe.v1i3.21

Kristiawan, M. (2015). A Model of Educational Character in High School Al-Istiqamah Simpang Empat, West Pasaman, West Sumatera. Research Journal of Education, 1(2), 15-20.

Kristiawan, M., Nizarani., \& Syamsidar. (2019). Role of School on Forming Character of Z-Generation Through Entrepreneurial Skills. International Journal of Scientific \& Technology Research, 8(10).

Kristiawan, M., \& Rahmat, N. (2018). Peningkatan Profesionalisme Guru Melalui Inovasi Pembelajaran. Jurnal Iqra' : Kajian Ilmu Pendidikan, 3(2), 373 - 390. https://doi.org/10.25217/ji.v3i2.348

Suratman, S., Arafat, Y., \& Eddy, S. (2020). The Influence of Principal's Leadership and Teacher's Competence toward Teacher's Performance in Indonesia. Journal of Social Work and Science Education, 1(2), 96104. Retrieved from https://ejournal.karinosseff.org/index.php/jswse/article/view/32

Sutopo. (2002). Metodologi Penelitian Qualitatif I: Dasar Teoritis dan Karakteristiknya. Surakarta: UNS.

Rahmadoni, J. (2018). Isu Global Manajemen Pembiayaan Pendidikan di SD Indonesian Creative School Pekanbaru. Jurnal Manajemen, Kepemimpinan dan Supervisi Pendidikan 3(2), Juli-Desember 2018.

Rohma, S., Harapan, E., \& Wardiah, D. (2020). The Influence of School-Based Management and Teacher's Professionalism toward Teacher's Performance. Journal of Social Work and Science Education, 1(1), 13-23. Retrieved from https://ejournal.karinosseff.org/index.php/jswse/article/view/6

Rusdiana \& Irfan, M. (2014). Sistem Informasi Manajemen. Bandung: Pustaka Setia.

Wachidi., Rodgers, A., \& Tumanov, D. Y. (2020). Professional Competence Understanding Level of Elementary School in Implementing Curriculum 2013. International Journal of Educational Review Vol. 2, Issue 99-105. Retrieved from https://ejournal.unib.ac.id/index.php/IJER/issue/view/814 